Journal of Management and Business Application

\title{
INFLUENCE OF LEADERSHIP, MOTIVATION, SALARY, AND INCENTIVE TOWARD EMPLOYEE PERFORMANCE PT. CEMENT PUGER JAYA RAYA SENTOSA
}

\author{
Fatim Matus Zahro ${ }^{1}$ \\ Agustin HP ${ }^{2}$ \\ Saiful Amin ${ }^{3}$ \\ Higher Education of Economic Mandala \\ E-mail: saiful@stie-mandala.ac.id
}

\begin{abstract}
This study aims to determine the effect of leadership style, motivation, salary, and incentives on the performance of employees of PT. Cement Puger Jaya Raya Sentosa. The population in this study were 238 employees. The total sample of 110 respondents was selected based on proportional sampling. The data analysis method in this study uses multiple linear regression analysis. The results showed that the leadership style variable had a significant effect on employee performance motivational variables have no significant effect on employee performance; Employee salary variable significantly influences employee performance; Motivational variables significantly influence employee performance at PT.Cement Puger Jaya Raya Sentosa. While the incentive variable has a significant negative effect on employee performance at PT.Cement Puger Jaya Raya Sentosa.
\end{abstract}

Keyword: Leadership Style, Motivation, Salary, Incentives, Performance

\section{INTRODUCTION}

Changes that occur in the era of globalization move with special characteristics that are difficult to predict, surprising, complex, and trigger various conflicts within companies or organizations. The high and sustainable competitiveness that an organization must possess can only be achieved through the high competitiveness of its human resources (HR). The success of an organization depends on its ability to manage the various resources it has. One very important thing is human resources (HR). Resources, in this case, our employees, other than implementing elements of policies in public organizations, they are also beings who have certain thoughts, feelings, and expectations. Every organization will always try to improve and improve the performance of its employees, the goal is that what the company's goals and objectives will be achieved (Sirait, 2006: 5)
According to Hamali (2016) Performance is the result of work that has a strong relationship with the organization's strategic objectives, customer satisfaction, and contributing to the economy. Performance is about doing work and the 
results achieved from the work and what is done by how to do it. The explanation above explains a result achieved by a person or employee in carrying out their duties. A company organization must also have a leader who can monitor employee performance and also in theory the leader also influences the company's managerial. Therefore, a company leader must not only be firm and responsible but also must have a different style of leadership and characteristics. Besides that encouragement or motivation is also needed by a leader for employees to improve their performance. Motivation is something that encourages others to take action employees also have motivation so they want to work (Istijanto, 2005).

In addition to leadership style and motivation some factors influence employee performance, namely salary, and incentives. According to Tulus, (2011: 140) "Salary is the amount of money received by majors and administrative staff for the contribution of his services, who receive money with a fixed amount based on monthly rates". With a salary that is appropriate to his job, an employee will fulfill his responsibilities as an employee. Not only salary, but incentives also need to be done in a company, incentives that make their enthusiasm for employees and are obtained according to performance, this will affect the high performance of subordinates or employees. because it can create a passion for employees. Mangkunegara, (2004: 89) expressed his opinion about intensive, is an award in the form of material given by the leadership of the organization to employees so that they work with high motivation and achievement in achieving organizational goals. The incentive becomes a special encouragement for an employee and the company can also excel in achieving the goals of a company.

This research was conducted at PT. Cement Puger Jaya Sentosa, P uger - J bucket. The company is engaged in the cement industry, manufacturing cement, and marketing cement to various regions. PT. Cement Puger Jaya Raya Sentosa is a company that is still relatively new. With so many competitors in the city of Jember, this company is demanded to always produce sturdy and quality products to be able to compete with other cement production. Current conditions at PT. Cement Puger Jaya Raya Sentosa is very supportive to manage the product more than before, because of the performance of employees who work at the company has a great responsibility for their work, therefore the company's leaders are responsible for what is done by their employees, even the leaders in the company really protect its employees and have a different leadership style.

Style of leadership at PT. Cement Jaya Raya Sentosa applies a leadership style that is in line with the character of subordinates or employees, the majority of whom possess a fairly hard character. And leaders in the company have created the perception of subordinates to consider themselves as a leader who is worthy of being loved, trusted, and followed as well as meeting the criteria of leaders who can provide peace of mind in working, not only leadership style, as for other factors such as motivation that is needed by an employee to improve its performance. Leaders in these companies always motivate their employees with the typical style of a leader. As for salaries that are following the UMR (Regional Minimum Wage) and according to the contract in force in the company, the incentives that make their enthusiasm for employees and get following performance, then it will affect the high performance of employees. This study aims to determine the effect of leadership style, motivation, salary, and incentives on the performance of employees of PT. Cement Puger Jaya Raya Sentosa .

Widodo (2006: 78) states that performance is carrying out an activity and perfecting it following its responsibilities with results as expected. According to Keban (2004: 194) states that: "individual 
employee performance can be seen from whether the mission and goals of employees following the mission of the institution, whether employees face obstacles in working and achieving results, whether employees have the mental, physical, emotional ability to work, and whether they have high motivation, knowledge, skills, and experience at work.

According to Thoha (2013: 49) leadership style is the norm of behavior used by someone when the person is trying to influence the behavior of others as he sees it. Meanwhile, according to Rivai (2014: 42 ) leadership style is a set of characteristics used by leaders to influence subordinates so that organizational goals are achieved.

Motivation is something that encourages others to take action employees also have motivation so they want to work (Istijanto, 2005). Simon (1997: 276) clearly defines in his research that what is important for all companies is to motivate their employees to achieve organizational goals. Pfeffer ( 1998 ) also revealed in his research that all companies have learned tactics to utilize and manage their employees in achieving long-term excellence.

Sincerely, (2011: 140) " Salary is the amount of money received by the power of managerial and administration for contributing his services, which receive money at a fixed amount monthly rate. In general, it can be said, that the salary component that a person receives, generally consists of: Basic Salary, various benefits, various deductions. According to Mangkunegara, (2004: 89) Incentives are an appreciation in the form of material given by the leadership of the organization to employees so that they work with high motivation and achievement in achieving organizational goals.

Research related to factors that influence employee performance has been done by several previous researchers, among others, Hariadi (2017) stated that workers compensation, leadership style, and work motivation have a significant influence on employee performance at PT. Semen Gresik (Persero) . Subianto, ( 2016 ) states that the salary and incentive a significant influence on employee performance at PT. Serba Mulia Auto in West Kutai Regency . In addition, Prasetio (2016) states that motivation has a significant effect on the performance of employees of PT. Semen Padang Bureau of General Workers. Riyadi, ( 2016 ) also states that financial compensation, leadership style, and work motivation influence employee performance in manufacturing companies in East Java Based on some of the above research statements, the hypothesis and conceptual framework in this research are as follows .

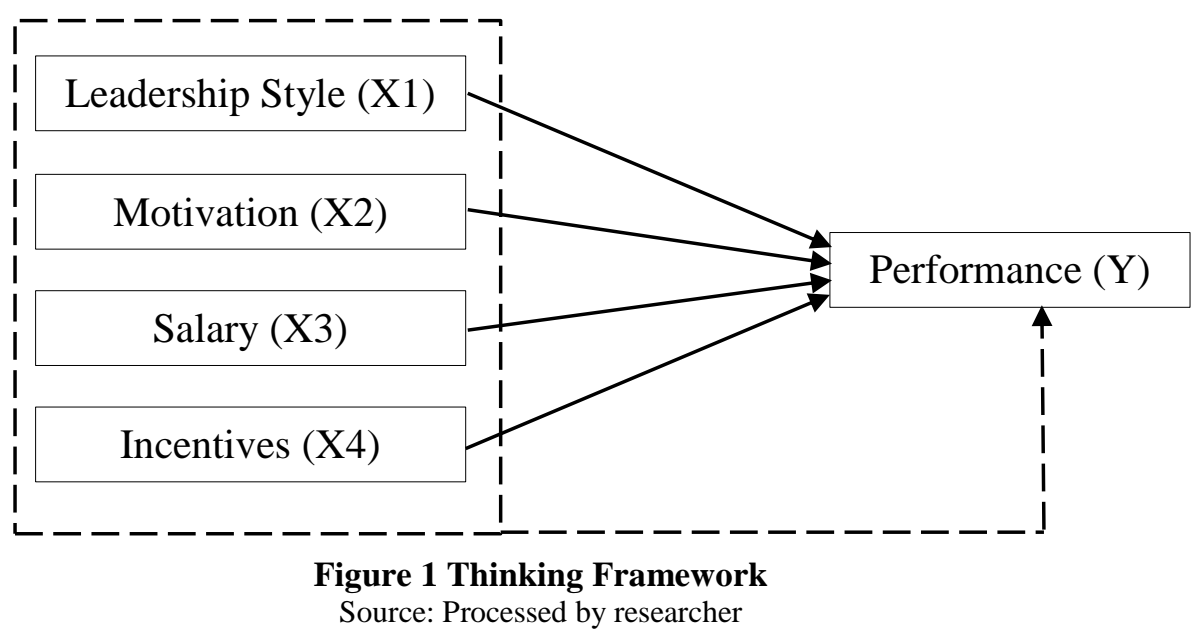

Based on the presentation of the style, motivation, salary, and incentives for material and the framework above, a the performance of employees of PT. hypothesis is taken, namely "leadership Cement Puger Jaya Raya Sentosa ". 


\section{RESEARCH METHODS}

This research is a type of quantitative research. Quantitative research is a research method in the form of numbers and analysis using statistics, especially regarding what has been examined, Sugiyono (2012) . The population in this study were 238 respondents who were employees of PT. Cement Puger Jaya Raya Sentosa. The sample in this study were 110 respondents who were determined based on the technique of determining the number of samples using the Slovin formula.

$$
n=\frac{N}{1+N(e)^{2}}
$$

Where:

$n$ : number of samples

$\mathrm{N}$ : total population

e: percentage of errors that are tolerated in sampling. ( $7 \%$ or 0 , 07 )

So the number of samples obtained are:

$$
n=\frac{238}{1+238 X(0,07)^{2}}
$$

$$
n=\frac{238}{1+1,1662}=110
$$

This study uses a non random sampling technique by using proportional sampling is a sampling that takes into consideration the elements or categories in the study population. Sugiyono (2003: 7478) . The proportion of the sample of this research can be seen in the following tablet

Table 1 Number of Employee Samples

\begin{tabular}{|l|l|c|c|c|}
\hline No & Information & Population & $\begin{array}{c}\text { Sample } \\
\text { Formula }\end{array}$ & total \\
\hline 1 & $\begin{array}{l}\text { Permanent } \\
\text { employees }\end{array}$ & 210 & $\begin{array}{c}210 / \\
238 \times 110\end{array}$ & 97 \\
\hline 2 & $\begin{array}{l}\text { Contract } \\
\text { employees }\end{array}$ & 28 & $\begin{array}{c}28 / \\
238 \times 110\end{array}$ & 13 \\
\hline \multicolumn{2}{|c|}{ Total } & $\mathbf{2 3 8}$ & & $\mathbf{1 1 0}$ \\
\hline
\end{tabular}

Source : Personalia PT. Cement Puger Jaya Raya Sentosa Jember

Data analysis method in this research uses multiple linear regression analysis . Regression is a systematic process of estimating what is most likely to happen in the future based on past and present information held so that errors can be minimized. The use of regression in this study is one of them to predict the dependent variable $(Y)$ if the independent variable $(\mathrm{X})$ is known. (Kuncoro and Riduwan, 2007 ) . Hypothesis testing of data using $t$ test to determine the effect of leadership style, motivation, salary, and incentives on the performance of employees of PT. Cement Puger Jaya Raya Sentosa.

\section{RESULT ANALYSIS}

\section{Test data validity}

Validity test in this study used item analysis that correlates the score of each item with the total score which is the sum of each item score. Validity test is used to measure the validity of a questionnaire. By comparing $\mathrm{r}$ arithmetic and $\mathrm{r}$ tables. The statement item is said to be valid if the value of $r$ is calculated $>r$ table . Based on the results of the validity test that has been done shows that all indicators on the variables of leadership style, motivation, salary, performance incentives, have a rcount value greater than the r-table value (0.187) . In addition the significance value on all variables has a significance value smaller than 0.05 . So that these results can be concluded that all indicators in this study proved valid

\section{Data reliability test}

Reliability test is a tool to measure a questionnaire which is an indicator of a variable or constructs. A questionnaire is said to be reliable or reliable if a person's answer to a statement is consistent from time to time. This study uses the Cronbach's Alpha technique to measure reliability. Cronbach 'Alpha is a benchmark used to interpret correlations between scales made with all existing variable scales. A construct or variable is declared reliable if it gives a Cronbach 'Alpha value> 0.6 . The results of the data reliability test can be seen in the following table 2. 
Table 2: Data reliability test results

\begin{tabular}{|c|c|c|}
\hline Variable & $\begin{array}{c}\text { Cronbach } \\
\text { 'Alpha }\end{array}$ & Information \\
\hline $\begin{array}{c}\text { Leadership } \\
\text { Style }\end{array}$ & .888 & Reliable \\
\hline Motivation & 0.724 & Reliable \\
\hline Salary & 0.865 & Reliable \\
\hline Incentives & 0.928 & Reliable \\
\hline $\begin{array}{c}\text { Employee } \\
\text { Performance }\end{array}$ & 0.889 & Reliable \\
\hline
\end{tabular}

Based on table 2 above shows that the leadership style research variable is said to be realiable because Cronbach's Alpha value $>0.6$ is equal to 0.888 . The motivation variable is said to be reliable because the Cronbach's Alpha value <0, 6 is equal to 0.724 . The salary variable is said to be reliable because the Cronbach's Alpha value $>0.6$ is equal to 0.865 . The incentive variable is reliable because the Cronbach's Alpha value> 0.6 is 0.928 and the employee performance variable is said to be reliable because the Cronbach's Alpha value> 0,6 is 0.851 .

\section{Test data normality}

Normality test aims to determine whether the data obtained are normally distributed or abnormal. Normally distributed data can minimize the occurrence of bias. Data normality testing is done by Kolmogrov-sminov test
(Ghozali, 2001: 83). The criteria for normality test are if the value is significant $>0.05$, then the research data is norm distribution 1 . Data normality test results can be seen in the following table :

Table 3 Data normality test results.

One-Sample Kolmogorov-Smirnov Test

\begin{tabular}{|ll|r|}
\hline & & $\begin{array}{r}\text { Unstandardiz } \\
\text { ed Residual }\end{array}$ \\
\hline $\mathrm{N}$ & Mean & 110 \\
Normal Parameters & a,b & .0000000 \\
Most Extreme Differences & Std. Deviation & 2.59139350 \\
& Absolute & .062 \\
& Positive & .062 \\
Test Statistic & Negative & -.044 \\
Asymp. Sig. (2-tailed) & & .062 \\
\hline
\end{tabular}

a. Test distribution is Normal.

b. Calculated from data.

c. Lilliefors Significance Correction.

d. This is a lower bound of the true significance.

Source: Processed by researcher

\section{Analysis of Multiple Linear Regression}

Linear regression analysis is a process of estimating systematically about what is most likely to occur in the future based on past and present information held so that errors can be minimized. The use of regr e si in this study is one of them to predict the dependent variable (Y) if the independent variable $(\mathrm{X})$ is known (Kuncoro Riduwan 2007: 83). The results of multiple linear regression analysis in this study can be seen in the following table 4 :

Table 4 Results of multiple linear regression analysis

Coefficients $^{\mathrm{a}}$

\begin{tabular}{|c|c|c|c|c|c|c|}
\hline \multirow[b]{2}{*}{ Mode } & & \multicolumn{2}{|c|}{ Unstandardized Coefficients } & \multirow{2}{*}{$\begin{array}{c}\text { Standardized } \\
\text { Coefficients } \\
\text { Beta }\end{array}$} & \multirow[b]{2}{*}{$t$} & \multirow[b]{2}{*}{ Sig. } \\
\hline & & $B$ & Std. Error & & & \\
\hline \multirow[t]{5}{*}{1} & (Constant) & 15.819 & 2.170 & & 7.288 & .000 \\
\hline & gaya kepemimpinan & .516 & .086 & .465 & 5.983 & .000 \\
\hline & motivasi & -.103 & .139 & -.085 & -.737 & .463 \\
\hline & gaji & .205 & .070 & .256 & 2.908 & .004 \\
\hline & insentif & -.270 & .058 & -.497 & -4.636 & .000 \\
\hline
\end{tabular}

a. Dependent Variable: kinerja karyawan

Based on the results of the multiple linear regression analysis above shows that the leadership style variables significantly influence employee performance ; Motivational variables do not significantly influence employee performance; Employee salary variable significantly influences employee performance ; Motivational variables significantly influence employee performance at 
PT.Cement Puger Jaya Raya Sentosa . While the incentive variable has a significant negative effect on employee performance at PT.Cement Puger Jaya Raya Sentosa .

\section{Coefficient of Determination}

According to Ghozali (2011: 87) the coefficient of determination (R2) is used to determine the percentage contribution of the simultaneous influence of independent variables on the dependent variable. The results of $\mathrm{R} 2$ can be seen in Table 5 below :

Table 5 Model Summary

\begin{tabular}{|l|c|r|c|c|}
\hline Model & R & R Square & $\begin{array}{c}\text { Adjusted R } \\
\text { Square }\end{array}$ & $\begin{array}{c}\text { Std. Error of } \\
\text { the Estimate }\end{array}$ \\
\hline 1 & $.704^{\text {a }}$ & .495 & .476 & 2.540 \\
\hline
\end{tabular}
a. Predictors: (Constant), insentif, gaya kepemimpinan, gaji,
motivasi

From the calculation of Table 5 above shows that the coefficient of determination (adjuted R2) obtained is 0.476. This means that employee performance contributed $47.6 \%$ by leadership style (X1), motivation (X2), salary (X3), and incentives (X4), while the remaining $52.4 \%$ was influenced by variables - other variables not included in the this research model.

\section{INTERPRETATIONS}

a. The Influence of Leadership Style on Employee Performance at PT. Cement Puger Jaya Raya Sentosa

Based on the results of hypothesis testing states that leadership style has a significant effect on employee performance. This means that the better the leadership style, the better the employee performance. Leadership style in this research is measured by indicators such as leaders having the ability to make decisions, have the ability to motivate, the ability to communicate, the ability to control subordinates, the ability of responsibility, the ability to control emotions. This research supports the research conducted by Galih Hariadi (2017) stating that leadership style has a significant effect on employee performance, besides Slamet Riyadi (2016), and Fanni Adhistya Italiani (2015). states that leadership style has a positive or significant influence on employee performance.

Based on the results of the study showed that the majority of respondents answered agreed to the statement that the leadership was able to make decisions appropriately, in the sense that the leadership at PT. Cement Puger Jaya Raya Sentosa has done the task after the SOP. Besides the leadership can provide encouragement or motivation to employees to use all their abilities at work, meaning that encouragement given by the leadership can also have a positive impact on employees. So that the instructions given can be understood by employees and employees have no difficulty with the direction given by the leadership. Supervision given by the leader can be followed well by employees, therefore employees feel they have a great responsibility for the work they do and also as a leader has a high responsibility for their work and the work of their employees. In making decisions about the leadership of PT. Cement Puger Jaya Raya Sentosa can control herself and not be emotional because it can affect the company's goals. Leadership style is a leader who must apply the leadership style to manage his subordinates because the leader will greatly affect the success of the organization to achieve its goals. The company's leadership always gives the right and systematic decisions to the problems faced by the company, motivates and encourages its employees to use all their abilities at work, and can understand every instruction and direction given by the leader and also the leader provides good supervision of employees, has responsibility high responsibility in every job he has and can also control themselves and not emotional in making decisions. 
b. The Influence of Motivation on Employee Performance at PT. Cement Puger Jaya Raya Sentosa

Based on the results of hypothesis testing states that motivation does not significantly influence employee performance. High and low motivation activities provided by the leadership can not improve performance. Based on the results of researchers show that several things make the motivation factor does not affect employee performance. Among other things companies do not always give awards for employee performance, lack of interaction between employees and leaders because of the leadership. This can result in decreased employee performance despite the motivation given by the great leadership of its employees, therefore as a leader not only motivates its employees but also has to see and hear what employees are complaining about. Motivation is something that encourages others to take action and employees also have motivation so that they want to work. This research is contrary to the results of research conducted by Galih Hariadi (2017) that motivation has a significant effect on employee performance, in addition Rizal Dwi Prasetyo (2016) and Windhi Aprilia Murty (2012) which states that there is a significant influence of motivation on employee performance.

\section{c. Effect of Salary on Employee Performance at PT. Cement Puger Jaya Raya Sentosa}

Based on the results of hypothesis testing states that salary has a significant effect on employee performance. This means that the higher the salary the employee gets, the better the performance of the employee. The salary in this study is measured by indicators including the amount of basic salary received, the level of salary paid, fairness of salary distribution, salary increase according to labor laws, and job satisfaction. Based on the results of the answers of the majority of respondents answered agreed to prove that the salary received each month is appropriate and on time Because each region has different rules for providing salaries, so the employees of PT. Cement Puger Jaya Raya Sentosa receives salaries following the district of Jember and is given monthly, every salary given by the company PT. Cement Puger Jaya Raya Sentosa is given according to the level of work of its employees, meaning that the level of work is in accordance with the procedures in the company. The salary given by the company is also equivalent to the salary given by other companies because the leadership follows the applicable umr. In the payment of salaries of PT. Cement Puger Jaya Raya Sentosa is also in accordance with labor laws in force in the city of Jember and also salaries from companies have largely met the needs of life of employees. Salary is the amount of money received by majors and administrators for their service contributions, which receive a fixed amount of money based on a monthly rate.

This research supports research conducted by Monik Maifanda (2019), the insight is that there is a significant influence of salary on employee performance, besides Marianus Subianto (2016) and Dian Natalia (2015) which states that salary has a positive and significant effect on employee performance. Therefore it can be concluded that the hypothesis in this study is accepted. Salaries earned by employees are in accordance with the applicable umr in the city, salaries provided by the company according to the level of employment of employees, salaries of employees while others get in different companies, and companies use salary payment procedures in accordance with labor laws, salaries also earned by employees has fulfilled the necessities of life.

\section{d. Effect of incentives on employee performance at PT. Cement Puger Jaya Raya Sentosa}

Based on the results of hypothesis testing states that incentives have a significant negative effect on employee 
performance. This means that the higher the incentives provided will reduce employee performance. That based on the findings in the field, most respondents said that the greater the incentives given to employees, the higher the company's demands on employee performance, therefore some employees felt heavy with the demands given even though the employees got incentives. For example the existence of overtime or additional hours on employees causes the burden of employees to increase even though they get incentives. Incentives are rewards in the form of material given by the leadership of the organization to employees or employees so that they work with high motivation and achievement in achieving organizational goals. This research is contrary to the results of a study conducted by Marianus Subianto (2016) whose insight has a significant influence on employee performance, besides Dian Natalia (2015) and which states that incentives have a significant effect on employee performance

\section{CONCLUSION}

Based on the discussion in the previous chapter, it can be concluded that the leadership style variables significantly influence employee performance; Motivational variables do not significantly influence employee performance; Employee salary variable significantly influences employee performance; Motivational variables significantly influence employee performance at PT.Cement Puger Jaya Raya Sentosa . While the incentive variable has a significant negative effect on employee performance at PT.Cement Puger Jaya Raya Sentosa . This needs to be considered so that the leader can apply the leadership style according to the employee's needs in order to improve employee performance. And also the provision of salary which is very important for employees so that employee performance increases and the achievement of company goals .
Based on the research conclusions, it can be seen that the leadership style, salary has a positive effect on employee performance. This needs to be considered so that the leader can apply the leadership style according to the employee's needs in order to improve employee performance. And also the provision of salary which is very important for employees so that employee performance increases and the achievement of company goals. Suggestions to be conveyed by researchers for further research is to add or examine other new variables such as the work environment, work discipline, safety and health (safety, health and work safety) and so on which are thought to influence employee performance. this research is expected to be used as the development of knowledge for those who will continue this research or who will make similar research so that it is expected to continue to be exploited and developed in science, especially in related institutions.

\section{REFERENCES}

Adhistya Fanni Italiani. 2015 " The Effect of Transformational and Transactional Leadership Styles on Employee Performance of the Department of Human Resources PT. Semen Gresik (Persero) Tbk ". Journal of Business and Management Vol. 6 No. August 1, 2015.

Amin, Saiful, Dimyati, M., \& Firdaus, M. (2016). The Effect of Corporate Image and User Image on Purchasing Decisions of Sharia Banking Services in Jember . (1), 501-518. Retrieved from http://jurnal.stiemandala.ac.id/index.php/relasi/article /view/90

Dwi Prasetio Rizal, Puspita Wulansari. 2016 " The Effect of Motivation on Employee Performance of PT. Semen Padang General Workers Bureau ". e-Proceeding of Management: Vol. 3, December 3, 2016 | Page 2999 
Ghozali, Imam. 2011, Multivariate Analysis Application with the IBM SPSS 19 Program, 5th Edition. Diponegoro University Publisher Agency, Semarang.

Ghozali, Imam. 2013, Multivariate Analysis Application with the IBM SPSS 21 Update PLS Regression Program . 7th edition, Diponegoro University Publisher Agency, Semarang.

Greer, Charles R. 1995 Strategy and Human Resources, Published by Pearson Custom Publishing.

Hamali Arif Yusuf. 2016, Understanding of Human Resource Management . Caps. Yogyakarta.

Hariadi Galih. 2017 " The Effect of Compensation, Leadership Style and Motivation on Employee Performance (Study at PT. Semen Gresik (Persero) Tbk in Gresik". Thesis article of Muhammdiyah University, Jember.

Hasibuhan, Malay. 2003, Human Resource Management. Revised Edition, Bumi Aksara, Jakarta.

Hasibuhan, Malay. 2004, Human Resource Management . Bumi Aksara, Jakarta.

Hasibuhan, Malay. 2014, Human Resource Management. Bumi Aksara, Jakarta.

Hidayatullah Taufiq . 2014 " The Effect of Motivation and Job Satisfaction on Manufacturing Employee Performance in Karawang (Case Study at PT YPMI )". Journal of Management \& Creative Business.

Justin T. Sirait, 2006. Understanding aspects of Human Resource Management in Organizations. Gramedia Widiasarana Indonesia, Jakarta.

Maifanda Nonik, Muhammad Ramadhan Slamet. 2019 " The Effect of Salary, Flexible Working Hours and Stress Work on Employee Performance in Companies in Batam City" . Journal of Applied Managerial Accounting Vol. 3, No. 1, March 2019, Page 8195.
Mangkunegara A Prabu. 2009, Human Resource Management. PT. Teen Rosdakarya. Bandung.

Mathis, 2006. Page : 113 " Factors That Affect Performance ".

Megawati Desi, 2018 " Implementation of Marketing Communication at PT. Cement Puger Jaya Raya Sentosa ". Jember University Thesis Article.

Mischel, Armstrong, 1999 Page 15 Human Resource Management . Sofyan and Haryanto's translation. PT Elex Media Komputindo. Jakarta

Ms. Fadly 2012 " The Effect of Incentives, Education and Training Levels on Employee Performance at PT. Semen Bosowa ". Hasanuddin University Thesis Thesis Article.

Monika, 2016 " The Effect of Organizational Compensation and Climate on Employee Performance, with Organizational Climate as an Intervening Variable.", A case study of PT. Cement Puger Jaya Raya Sentosa ". Thesis Article Sanata Dharma University Yogyakarta.

Mulyadi, 2013 Page 373 . Accounting System , Jakarta: Salemba Empat publisher.

Natalia Dian. 2015 " Analysis of the Effects of Incentives, Salaries and Motivation on Employee Performance at PT. Bumi Damai Utama ". Thesis Article Nusantara University PGRI Kediri.

Statutory Regulations: Law Number 13 Year 2003 Regarding Employment

Rahmad K, Iwan. 2011 " The Effect of Motivation and Organizational Culture on the Performance of Employees in the Production Section of PT. Semen Gresik (Persero) Tbk in Gresik " . National Development University Thesis Article "VETERAN".

Riduwan and Kuncoro. 2007. Page: 83 How to Use and Use Path Analysis Alfabeta Publisher, Bandung.

Riyadi Slamet. 2011. " The Effect of Financial Compensation, Leadership Style, and Work Motivation on 
Employee Performance in Manufacturing Companies in East Java". J urnal Management and Entrepreneurship, Vol.13, No. March 1, 2011: 40-45.

Robbins. 2006, Organizational Behavior. Issue 10, PT. Gramedia Group Index, Jakarta.

Saifuddin Mubarok E. 2017, Human Resource Management, Introduction to Competitive Advantage. Publisher In Media.

Sevilla, Consuelo G. et. el . 2007 " Research Methods" . Rex Printing Company. Quezon City.
Subianto Marianus . 2016 " The Effect of Salary and Incentives on Employee Performance at PT. Serba Mulia Auto in West Kutai Regency ". eJournal of Business Administration, 2016, 4 (3): 698-712.

Sugiyono, 2003. Business Research Methods. Bandung, Ministry of National Education Language Center Sugiyono, 2017. Research, Quantitative, Qualitative, and $R \& D$ Methods. Publisher: Alfabeta 